\title{
Understanding the anatomy of religion as basis for religion in education
}

\begin{abstract}
Author:
Johannes L. van der Walt ${ }^{1}$

Affiliation:

${ }^{1}$ School of Education, North-West University,

Potchefstroom campus,

South Africa

Note:

Hannes van der Walt, who retired at the end of 2000 as Dean of the Faculty of Education at the former Potchefstroom University, is a specialist researcher attached to the Faculty of Education Sciences of the North-West University (Potchefstroom campus). He specialises in Philosophy of Education and Religious Education Studies.
\end{abstract}

Correspondence to: Hannes van der Walt

Email:

hannesv290@gmail.com

Postal address:

18 The Vines, Luneville Road, Lorraine, Port Elizabeth 6070, South Africa

Dates:

Received: 27 July 2010 Accepted: 16 Dec. 2010

Published: 04 July 2011

How to cite this article: Van der Walt, J.L., 2011, 'Understanding the anatomy of religion as basis for religion in education', HTS Teologiese Studies/ Theological Studies 67(3), Art. \#924, 7 pages. doi: $10.4102 /$ hts v67i3. 924
This article sprung from previous structural analyses of religion as onticity, but went somewhat further by placing more emphasis on encounters with the numinous as the core of religion, as well as on the dynamic character of religion. In doing so, this analysis methodologically transcended the limitations of a structuralist view of religion. The post-structuralist approach that was followed, assigns greater prominence to the interpretive and constructivist activities of the actors involved in religious experience. Application of this expanded view of religion to the South African Policy on Religion and Education (2003) demonstrated that the Policy caused a break between the various facets of religion education and resultantly disrupted the wholeness of religion education.

\section{Introduction}

Religion in education (schools) has for a long time now been a controversial subject in South Africa and elsewhere (Van der Walt 2009a). In one of a series of recent developments regarding religion in South African schools, self-confessed agnostic scholar George Claassens announced his intention to persecute public (state) schools that offered Christian education on the grounds that in terms of the 2003 Policy on Religion and Education, confessional religion education had been officially prohibited in such schools (De Villiers 2009:1). He found this practice also to be in contravention of the Constitution of the Republic of South Africa (Act 108 of 1996). According to Du Preez (2009:388), Claassen later decided not to proceed with his plan as a result of pressures exerted on him and his family by proponents of confessional religion education in public (i.e. state) schools.

Claassen is not alone in denouncing confessional religion education in public schools. Roux and her co-researchers (refer Roux 2003; Ferguson \& Roux 2004; Roux \& Du Preez 2005:279ff.; Roux $2005,2006)$ are also critical of the fact that many South African schools persist with confessional religion education despite official policy. In their opinion, religious literacy programmes should be offered in public schools instead of confessional religion education; the former will better equip learners to cope with the religious diversity prevalent in South African schools as well as in the broader community. A Professor of Theology of the Reformed Churches in South Africa, Kruger (2009), also joins forces with them in arguing for confessional religion education to be removed from public (state) schools. He contends, amongst others, that confessional religion education, specifically Christian religion education, cannot be adequately presented in the conditions currently prevalent in public schools. It should therefore rather be provided by the church, the parental home and private (Christian) schools.

This conundrum of whether confessional religion education should be included in the formal curriculum of the public (state) school is understandably not restricted to South Africa. Literature abounds with reports about parents and teachers involved in the battle on both sides. Some of the contending parties have pursued their cause right up to the highest international courts and councils (see, for instance, Hagesaether \& Sandsmark 2006; Weisse 2003; Leirvik 2004).

My aim is to approach the problem of religion in and/or education from a different viewpoint. I contend that the place and role of religion in education cannot be properly determined unless one understands the anatomy of religion in its entirety. This thesis springs from the work of Abdool, Potgieter, Van der Walt and Wolhuter (2007), who describe religion as a multi-faceted phenomenon and claim that each of its facets has important pedagogical consequences for religion in and/or education. Although I concur with what they say (Abdool et al. 2007:545-547) about the basic structure of religion, I think that their analysis of the anatomy of religion is deficient on at least two counts, namely their failure to recognise the numinous as the core of religion and their structuralist approach to the analysis of religion. 
Firstly, evidence will be presented to support the contention that our current view of the structure of religion should be improved by inclusion of the numinous, as well as that religion has to be viewed from a post-structuralist (interpretive-constructivist) vantage point to do justice to its dynamic nature. I shall then put the more detailed picture of religion that I proffer to the test by applying it to the South African Policy on Religion and Education that has been in effect since 2003. I intend to demonstrate that the Policy, as it stands, cannot do justice to religion education as a seamless whole.

\section{Methodology}

I follow an interpretive-constructivist and critical heuristic, the object of which is to determine the nature of a specific situation, in this case the religious diversity which has to be regulated in schools. This heuristic enables one to discover the meaning a certain situation has for those participating in it, in this case in the religious diversity in schools (Feinberg \& Soltis 1985:89; McKay \& Romm 1992:48ff.). Interpretiveconstructivist researchers maintain that there are multiple constructed realities and rather than trying to be totally objective, they apply their own professional judgements and perspectives when interpreting the data. They insist that the meaning of particular forms of social life, in this case education and religion, should be interpreted and thus reconstructed, in order to be understood. As a result, they place more emphasis on values and context than on hard and fast data (McMillan \& Schumacher 2010:6). Application of this heuristic enables me to look at religion as such and how it should be regulated in (state, public) schools as constructed and interpreted realities of human interaction in social context. I draw meaning from the analyses of the constructs education and religion and of associated constructs. This provides me with insights of a hermeneutical, interpretive and qualitative nature and of the various contexts in which they appear (Onwuegbuzie, Johnson \& Collins 2009:122-123). The post-conflict type of critical analysis (Jansen 2009:255 et seq.) that I combine with interpretive-constructivism, furthermore helps me understand the sources of discontent about how religion is currently accommodated in education (schools) and 'to demonstrate that such discontent can be eliminated by removing the structural contradictions that underlie it' (Babbie \& Mouton 2004:36).

Although I understand the importance of scientific objectivity and disinterestedness, I approach the problem of the anatomy of religion and its pedagogical ramifications as a Christian educationist. All the research methods mentioned previously are therefore somehow interpretively and constructively imbedded in my belief and conviction system. In saying this, I align myself with De Muynck and Van der Walt's (2006:41) view that we can only interpret, construct and criticise that which we have at hand as already having been given to us in creation and which are subject to the order-giving laws of God as the Law-giver. Our activities as knowing subjects are confined to the boundaries of rationality. Put differently, our rationality is exercised within the boundaries of the lawful structure of reality that we experience as pre-given by God.

\section{Conceptual-theoretical framework}

The main thrust of Abdool et al.'s (2007) work regarding respect for and tolerance of other religions and their adherents in pedagogical settings is that students (learners, pupils), irrespective of religious affiliation, should attend the same schools and classes. Well-trained teachers (educators) should further guide them not only to understand the generic structure and significance of religion as a phenomenon, but also inculcate in them a spirit of respect for and tolerance of all the religions represented in their particular environs. They contend that if learners understood that all forms of religion had some or other form of spirituality at their core, they would be able to connect with one another at a deep spiritual level and that respect and tolerance would follow from that. This view of the structure of religion was retained in their subsequent publications (Van der Walt 2009a, 2009b; Van der Walt, Potgieter \& Wolhuter 2010).

In terms of Abdool et al.'s 'onion' metaphor, every form of religion, ranging from atheism through agnosticism and Gnosticism to the mainstream religions, consists of several layers, from the superficial and most conspicuous (rites, rituals, cults, worshipping practices) on the 'surface', to the least directly observable (i.e. the deepest, inner spiritual layer). Respect for and tolerance of their own and other religions can and should be brought home to learners with respect to each of these layers (Abdool et al. 2007:545-548).

Although this analysis of religion goes some distance towards understanding the structure of religion, I would argue that another structural element, the numinous, lie at the core of all forms of religion and not spirituality. Their 'onion' metaphor furthermore depicts religion as a static entity, consisting of a number of layers that can be theoretically peeled off one after the other for closer analysis; therefore, I also contend for the propriety of another metaphor, provisionally referred to as the 'smoke' metaphor, as a depiction of the dynamic 'structure' ${ }^{1}$ of religion. In terms of this metaphor, religion is not a static, concrete phenomenon ('thing'; static onticity) with a fixed structure, but rather something more like a constantly changing state of mind that expresses itself in a variable set of beliefs ${ }^{2}$.

1.'Structure' and other similar terms are in inverted commas to draw attention to the fact that we should not see religion as a hard and fast, unchangeable ontic structure. A facet of its onticity is its constantly changing, variable and dynamic character.

2.All people are religious, when looked at from the perspective of beliefs. Even atheists have firm beliefs. The self-acclaimed atheist, Ronald Aronson, who declares himself to be in the company of Sam Harris, Daniel Dennett, Richard Dawkins, himself to be in the company of Sam Harris, Daniel Dennett, Richard Dawkins, imbedded in nature, history, and society in ways that give our lives meaning and imbedded in nature, history, and society in ways that give our lives meaning and impose demands on us' (Aronson 2008:19). He prefers to answer the 'standard'
religious questions 'in terms of this world and this life' (Aronson 2008:20); therefore, religious questions 'in terms of this world and this life' (Aronson 2008:20); therefore,
Aronson is incorrect in thinking that some people can be 'irreligious' or 'in no way religious' (Aronson 2008:23, 29). He is correct, however, in arguing that many people have relinquished their faith in main stream religions; such people can indeed be regarded as 'disbelievers' in main stream religion, 'less driven by doctrine' and 'light on theology' (Aronson 2008:30, 32). John Gray (2003:3) concurs with the view that all people are believers. People think, for instance, that they belong to a species that can be master of their own destiny; they believe in progress. This is, according to him, faith and not science. Humanism is 'a doctrine of salvation; 'the belief that humankind can take charge of its destiny' (Gray 2003:16). Gray (2003:19-20, 26, $31,38)$ even refers to trust in science as religious or faith language: '... science does not yield any fixed picture of things, but by censoring thinkers who stray too far not yield any fixed picture of things, but by censoring thinkers who stray too far from current orthodoxies it preserves the comforting illusion of a single established worldview. ... To think of science as the search for truth is to renew a mystical faith ... Modern humanism is the faith that through science humankind can know the truth - and so be free'. 'Humanism is a secular religion'. Conscious mastery of humankind's existence is the 'creed of those who have given up irrational belief in God for an irrational faith in mankind. Sayers (2009) is also convinced that many people today who are atheist or agnostic in religion, are governed in their conduc by a code of Christian ethics which is so rooted in their unconscious assumptions that it never occurs to them to question it. 
This re-envisioning of religion helps us to see religion not as a 'thing' or an entity, but rather as a dynamic process involving all of its 'components'. It embodies the notion of dynamic interaction between the different 'layers', 'components' or 'elements' of religion. Given that religion is a dynamic state of mind and series of experiences, including of the numinous, terms such as 'structure', 'blueprint' or 'anatomy' seem inappropriate and should be relinquished in favour of more dynamic terminology.

\section{The numen at the heart of religion as dynamic entity}

Working on the analysis of Abdool et al. (2007), Van der Walt, Potgieter and Wolhuter (2010:36-37) contend that all forms of religion reveal the following basic structure:

- Religion has a directly observable outer 'layer', which is of a cultic or ritual nature (Greek leitourgia, Latin officia, English service, duty, ministry).

- Closely associated with this first 'layer' is the second: that of a sense of awe and respect owed to the god or gods (Greek eusebia, Latin reverentia, English reverence or worship).

- Religions tend to have a theological, dogmatic and confessional 'layer' (Greek dogma, derived from dokein, to seem good; Latin confessus, derived from confiteri, to admit).

- Religions also have a philanthropic or caring 'layer' (Greek philanthropia, philadelphia; Latin humanitas, caritas; English love of humanity, brotherly love, charity).

- Religions have a faith or 'pistic' 'dimension' (Greek pistis, Latin pietas, English faithfulness, loyalty).

- At a deep level, religions have a spiritual 'dimension' (Greek pneuma, Latin spiritus, English breath or spirit) ${ }^{3}$.

On Abdool et al.'s (2007) analysis of religion, understanding and tolerance amongst adherents of different religious groups, for instance in pedagogical settings, should in essence rest on an understanding of religions at the spiritual level, that is, the level that they assume to be the deepest or innermost 'level' of religion. As I have said, my analysis of religion reveals Abdool et al.'s view of religion to be inadequate in two respects: the true core of religion and its dynamic character.

\section{The numen at the heart of religion}

Despite the controversial nature of his theology, including his views about the numinous, my investigations lead me to

\footnotetext{
3.The proponents of this view of spirituality do not share Paley's (2008) scepticism about the use of the spirituality concept to describe phenomena that are in principle unreachable by science. Together with terms such as 'higher powers', 'the infinite', 'higher levels of existence', 'invisible forces', 'the transcendent', 'cosmic unity', 'eternity' and 'the numinous', Paley regards 'spirituality' as a 'concept of the supernatural', and as such, 'outside the bounds of scientific enquiry'. He remains sceptic about the scientific non-accessibility of spirituality and other supernatura phenomena. To his mind, 'spirituality' is an artificial concept and its use leads to spurious claims (Paley 2008:3, 9, 13, 14). He furthermore rejects the current 'stretch dynamic view' of spirituality, that is, as a most elastic concept that embraces almost every aspect of experience, a concept with patently religious connections and connotations (2008:6). Paley emphasises that he merely rejects the 'stretch dynamic connotations (2008:6). Paley emphasises that he merely rejects the 'stretch dynamic view of spirituality and not the various phenomena that the term is normally used to refer to. In his opinion, less religious terminology should be employed because that would render the phenomena more accessible to scientific enquiry (2008:14) Van der Walt (2009.3-4, 2009a.258-261) and De Muynck (2008:406) do not share Paley's views on the use of the term 'spirituality'. They insist on the use of the term, but restrict its meaning to religious phenomena and behaviour which are open to scientific scrutiny.
}

agree with Otto's remark that 'there is no religion in which [the numen or numinous] does not live as the real innermost core ... without it no religion would be worthy of the name' (Otto 1923:6). The second meaning of 'numen', provided by Sinclair (1999:1015), resonates with this view, namely that it is a guiding principle, force or spirit. The word is derived from Latin, literally meaning a nod (indicating obedience to a command) and figuratively denoting divine power. The numen denotes 'presence' and is a Latin term for the power of either a deity or a spirit that is present in places and objects, as in the Roman religion. ${ }^{4}$ The notion of 'nodding', contained in the numen concept, refers to a sense of inherent vitality and presiding and associations with notions of 'command' and 'divine majesty'. It is etymologically akin to a word used by Immanuel Kant, namely noumenon, a Greek word referring to an unknowable reality underlying all things (Wikipedia 2009b). According to Otto (1923:6), the numen or numinous was referred to in Hebrew as qadosh, to which the Greek agios and the Latin sanctus and more accurately later still, sacer, are the corresponding terms. In essence, numen refers to life-energy. This is the core meaning that I focus on in this discussion of numen ${ }^{5}$.

Numen refers to a quite specific element or moment in religious experience that is not rational in the normal sense of the word (though not irrational in the normal sense of the word). It is a non-rational, non-sensory experience or feeling whose primary and immediate object is outside the self. It therefore remains inexpressible, an (Gr.) arreton; ineffable ${ }^{6}$, in the sense that it completely eludes comprehension in terms of concepts, a concept of the 'supernatural' (Paley 2008:3). There is, according to Slater (2004:246), no means of sharing, affirming and acknowledging numinous experiences. Paul's encounter with the Lord on the road to Damascus comes to mind. According to Acts 9:7, the men travelling with him stood there speechless; they heard the sound but did not see anyone. Chopra (2009:215) refers to this encounter as 'spectacular', one that made of him 'a fiery believer' whose further life and work were an 'explosion of spirit'. On this account, Paul's conversion was an encounter with the Numinous: 'In a flash a sinner sees the light and recognizes God'. ${ }^{7}$ Augustine's descriptions of the conversions of a friend and of himself to the service of the Lord are also reminiscent

4.The many names for Italic gods may obscure this sense of a numinous presence in all the seemingly mundane actions of the natural world. The word 'numen' has several other meanings, for instance, it can refer to the imperial cult of ancient Rome, in other words to the guardian-spirit, 'godhead' or divine power of a living emperor. This meaning denotes a means of worshiping a living emperor without literally calling him a god. The word 'numen' is also used by sociologists to refer to the to the idea of magical power residing in an object, particularly when writing about nearly synonymous with 'mana' (referring to ideas about magic from Polynesia and south-east Asia) (Wikipedia 2009a).

$5 . I$ do not share the notion that numen refers to a life-energy that is inherent in al living beings which, according to the Wikipedia (2009a), seems to be a fairly universal archetype that appears in numerous ancient religions and systems of metaphysics.

6. Hewson and Carter (2007) found in their review of a book on the idea of the numinous in psychoanalysis that there have been many efforts to describe the numinous. From their overview, it is clear that there is no consensus about what precisely the numinous means or refers to. In their opinion, the 14 contributing authors in the book introduce the reader to paradox: they write papers about the ineffable numinous, treating it paradoxically as an epistemological subject (2007:237). On the other hand, as Mathew (2005:388) notes, although we cannot really know how it works across as Mathew (2005.388) notes, although we cannot really know how it works across the usefulness of a window that can swing open between the self and the other or the usefulness of a window that can swing open between the self
Other so that we can make use of the 'void within', the 'what is not'.

7.According to Surah XCVI, Mohammad had a similar experience. During this encounter he heard an awe-inspiring voice speaking; however, there were no witnesses, as Mohammad had retreated to a cave for meditation (Pickthall 1994:7-8). 
of encounters with the Numen. In the case of the former, Augustine relates:

Then suddenly, filled with an holy love, and a sober shame, in anger with himself he cast his eyes upon his friend, saying, 'Tell me, I pray thee, what would we attain by all these labours of ours? what aim we at? what serve we for? Can our hopes in court rise higher than to be the Emperor's favourites? and in this, what is there not brittle, and full of perils? and by how many perils arrive we at a greater peril? and when arrive we thither? But a friend of God, if I wish it, I become now at once.' So spake he. And in pain with the travail of a new life, he turned his eyes again upon the book, and read on, and was changed inwardly, where Thou sawest, and his mind was stripped of the world, as soon appeared. For as he read and rolled up and down the waves of his heart, he stormed at himself a while, then discerned, and determined on a better course; and now being Thine, said to his friend, 'Now have I broken loose from those our hopes, and am resolved to serve God; and this, from this hour, in this place, I begin upon (emphasis added).

(Augustine 1909-1914: Book 8, line 40)

His own encounter with the Lord was as follows:

Thou, O Lord, while he was speaking, didst turn me round towards myself, taking me from behind my back where I had placed me, unwilling to observe myself; and setting me before my face, that I might see how foul I was, how crooked and defiled, bespotted and ulcerous. And I beheld and stood aghast; and whither to flee from myself I found not. And if I sought to turn mine eye from off myself, he went on with his relation, and Thou again didst set me over against myself, and thrustedst me before my eyes, that I might find out mine iniquity, and hate it.

(Augustine 1909-1914: Book 8, line 41)

Experience of the numinous, says Mathew (2005:388), is like 'an experience out of the blue, from the other side of the rainbow'. It is possible, according to her (2005:385-386), that an experience may open a window in the perimeter of a person's experienced mind with the potential for connection (or even reconnection) with the numinous, or, as Greene $(2004: 29,31)$ refers to it, the 'totally other' super-nature.

Space constrains me from expanding much on the averred characteristics of the numinous or on experience of the numinous. Encounters with the numinous are only reserved for people; only a human being can feel connected with the numen or archè, which from then on forms the heart, core or reference point for the person, whether in transcendent or immanent sense (see Calvin 1584. I, ch. 3, paragraph 1; Barge 2004:39; Slater 2004:246, 251; Wilhelm 2004:565; Matthew 2005:386-390; Crosby 2007:508; Schlamm 2007:404-405; Swer 2008:245; Aronson 2008:20; Jung in Colman 2008:356, 362; Jarvis 2008:65). Connectedness with the numinous, in other words, religiosity-in-essence, forms part of a human being's search for meaning (Kruger, Lubbe \& Steyn 1996:4-5). The numinous provides religious knowledge inaccessible to rational understanding. It falls outside the limits of the canny, is contrasted with it and fills the mind with blank wonder (Schlamm 2007:405).

\section{The dynamic nature of religion}

According to Gibson (1984:6-12), a structuralist approach, in this case of religion (the seven 'layers' thereof: the six distinguished by Abdool et al. plus the numen or numinous at the heart of religion), embodies the following six structuralist ideas:

- It emphasises the wholeness of religion, despite the fact that it is perceived to consist of several 'layers'.

- Its reality does not lie in the different components or layers of religion, but in the relationships between them.

- The person who observes (analyses) religion becomes part of the religious system.

- The whole religious system maintains itself; it governs its parts such that they change, if required to do so, to ensure the preservation of the totality.

- One can only study and describe a structure, in this case, religion, at a given moment rather than its development over time.

- The laws of the entity (religion) are both structured and structuring, that is, they allow a dynamic between part and part, part and whole. In that dynamic, change is a necessary consequence. This transformation is a key idea of structuralism.

A structuralist description of religion goes some way towards explaining the 'anatomy' of religion, but it places insufficient emphasis on its dynamics. A post-structuralist perspective (McKay \& Romm 1992:48) is helpful here in that it depicts religion as a structure, the meaning of which is constantly (re-)constructed, (re-)constituted and sustained through the ongoing interpretive activities of the social actors (researchers like myself, readers of this article, people who practise a particular religion, believers, etc.). This constructive process is, however, not an epistemology of shaping knowledge out of nothing; knowledge is (re-)interpreted and (re-)constructed on the basis of a pre-given, law-governed reality or creation. The emphasis in an interpretive-constructivist approach is on the activity of all the participants, in other words, the transformation of knowledge (Lagerweij \& Lagerweij-Voogt 2005:286, 327).

In terms of a post-structuralist or constructivist approach, the different components or elements of religion are viewed as dynamics of religion as an onticity, that is, as an ontic being (literally: be-ing) that is constantly subject to dynamic change and adaptation, according to circumstance. Religion in any particular form should therefore not be seen as a monolithic system of neatly arranged compartments, components and/ or levels, but rather as an abundance of experiences and awarenesses that confusingly 'bleed' into one another and resultantly, changes shape continuously. To borrow a remark by Crosby (2007:508) from a slightly different context, it is a complex blending of unity and diversity, order and disorder, continuity and novelty, persistence and change.

After casting around for an appropriate metaphor to portray religion as dynamic entity, I found the following graphic to fit the bill:

This graphic (see Figure 1) portrays religion as a swirling, twirling and whirling spiral, less like a solar system with a central body and certain religious aspects orbiting around it, 


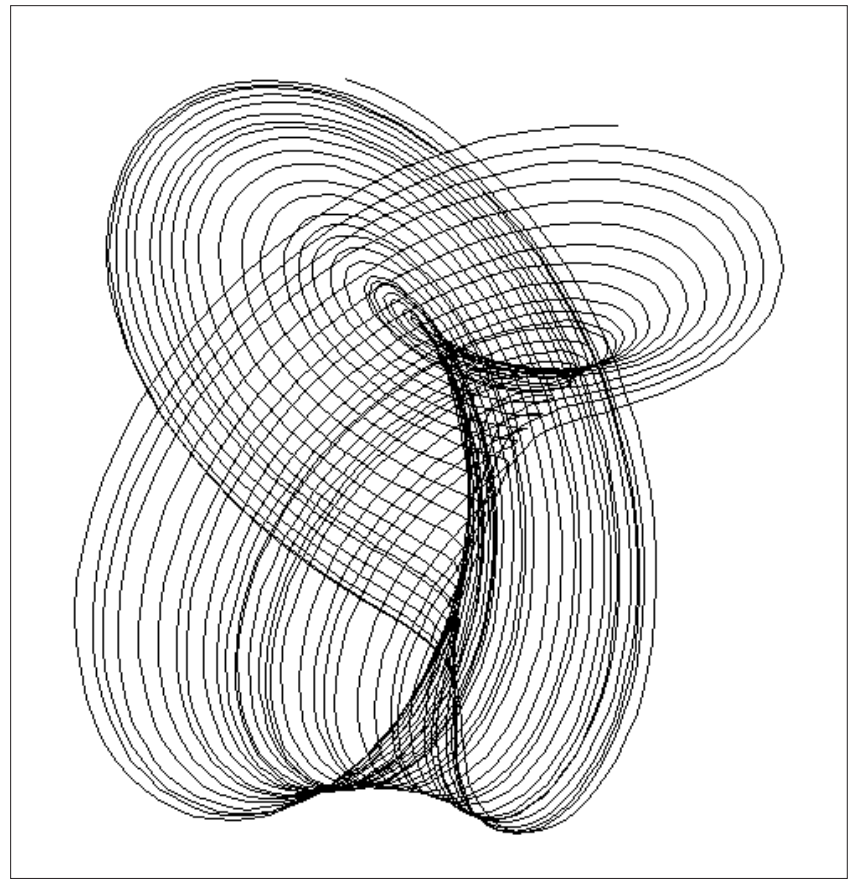

Source: Wikipedia (2009a)

FIGURE 1: Portrayal of religion as dynamic entity.

or a pyramid with the numinous, for instance, at the base and spirituality at the apex, or an onion, the layers of which can be figuratively or theoretically peeled off. The spiral, like a column of smoke, turns and returns again and again to the same point as it continues to grow in a particular direction. Like the particles in a column of smoke, the actual behaviour of the elements of religion appears unpredictable and random, but as Davies (1992:30-31) argues, nothing in creation behaves unrestrictedly chaotic in a lawless universe. The relative probabilities of the different possible states of the various elements of religion are determined within a law-governed cosmos. In doing what they do in response to the circumstances and as a result of human actions and decisions, the various elements of religion serve a creative purpose, namely, to provide form for something new (Young 2001:28). Although religion can be termed a 'structure', it is essentially a dynamic one, constantly subject to change depending on the interpretive and constructive actions of the actors involved. The job of the religion scientist is to uncover patterns in religion and to try to fit them in theoretical schemes. The question of why there are patterns (cosmic laws for religion) and why such theoretical schemes are possible, lies more in the ambits of philosophy and theology than in the scope of religion science as such (also see Davies 1992:31).

\section{The 'test': The complex structure of religion and the current South African Policy on Religion and Education (2003)}

The workability of the foregoing portrayal of religion as complex, multi-dimensional and above all, dynamic entity can be put to the test by looking at the current South African Policy on Religion and Education (2003). Before I do this, I have to point out that in previous publications I have been propounding two parallel arguments with regard to respect for and tolerance of religious diversity and differences in educational settings. Some publications argue for confessional and structural pluralism, that is, a system in which provision is made for the separate confessional religion education of students (learners, pupils) adhering to different religions, including in separate institutions (schools). I regard this strategy as of import for very young children who have not yet acquired a good mastery of the religion preferred by their parents. My parallel argument for accommodating learners adhering to different religions in one and the same class and school is arguably more appropriate for older learners or in situations where confessional and institutional pluralism is deemed impracticable.

Very young children should receive confessional religion education in their parental homes and in their religious institutions such as churches, mosques, temples and synagogues, for the simple reason that their tender minds will become confused if they were exposed to the tenets of several religions during the first few years of formal schooling. This will be detrimental to their mastering of their own religion(s). Students from the age of approximately 14 should be exposed to the various religions represented by the student population in their school in order for them not only to understand those religions, but also to learn to respect and tolerate them.

I base this thesis on the following. Every learner as a human being is essentially homo religiosus, in other words, religion forms an essential part of being human. Students have to encounter all the religions represented in their school in order to understand, know and respect their own religion as well as those of others. The assumption in the South African Policy on Religion and Education (2003: articles 54 and 55) that '(confessional) religious instruction (with a view to the inculcation or adherence to a particular faith or belief) is primarily the responsibility of the home, the family, and the religious community' and therefore 'may not form part of the formal school programme' cannot be supported. Religion is a whole, comprising various distinguishable elements; religion instruction (religious instruction, according to the Policy) should resultantly also be a seamless undertaking for the religious wholeness of the students to be safeguarded.

The South African Policy on Religion and Education (2003) causes an artificial rupture between on the one hand religion education, that is, instruction for the purpose of inculcating in young people the tenets of a particular faith and religious observances (article $58 \mathrm{ff}$.) and religion education as a formal examinable school subject (article $17 \mathrm{ff}$.) on the other. Most of the stipulations in the Policy are devoted to the latter as part of the formal school curriculum. What the Policy does is to destroy the unity of religion and hence that of religion education as an entirety. It bans a core aspect of students' religious experiences from the school to the parental home and the religious institution. Although it provides for the accommodation of religion instruction in schools (outside of 
the formal curriculum and school times), it places religion instruction in the hands of the parents and of clergy and not the students' regular teachers. This not only disrupts the unity and wholeness of religion and religion instruction, but also deprives the students from experiencing the richness of the religious diversity in their school.

The Policy also creates the danger of religious confrontation on the school grounds. Danger lurks when confessional religion is not fairly and equitably taught and discussed under regulated circumstances, with the necessary pedagogical expertise and guidance. The lack of pedagogical guidance in this respect in schools is detrimental to the creation of social capital in South Africa and therefore not in the interest of the common or public good.

Religion, composed of several elements or layers and assuming unpredictable shapes as a result of adherents' interpretations, constructions and meaning-giving, also embraces spirituality, defined by Nolan (2009:57) as the kind of subjective attitudes and personal consciousness we need in order to be at all times honest and fair, among other things' (also refer Rawls 2007:566). Spirituality, according to Abdool et al. (2007:547), embodies the human being's quest for depth and values and describes how people relate their beliefs and actions towards god(s) or God and/or otherness, to their own being and core values and express them in religious practices. Spirituality has to do with the inner life of the individual (Nolan 2009:58). These definitions imply that students inadvertently and unwittingly bring their spirituality as part and parcel of their entire religiosity to school with them and teachers should be afforded the time and opportunity to help them encounter the wealth of spiritual diversity thus brought to school.

Nolan's (2009:58-63) discussion of the role of spirituality pivots on two ideas. Firstly, spirituality is about the search for the truth about oneself, one's motives, obsessions, compulsions, desires, fears and self-centredness and about learning about love and compassion for others. It is about learning about oneself as one is and how to deal with the truth about oneself. Spiritual understanding of the self, he avers, helps one deal with one's intellectual pride, swollen ego, emotional immaturity, childishness, prejudice and partiality, self-centredness, competitiveness and individualism. Secondly, according to Nolan (2009:64), spirituality helps one transcend all of these aspects of self-centredness and to become what he terms an organic person, in other words, a person who serves the interests of social justice. The organic person, in this case student, is committed:

... to any change that is for the benefit of all the people. Another way of describing this is to say that the [organic person, i.e. the student] works for the common good, not for his or her own selfish interests nor for the interests of the ruling class.

(Nolan 2009:64-65)

My view about the place of religion in schools resonates with Nolan's about spirituality. The Abdool et al. (2007) analysis revealed the importance of spirituality; together with experience of the numinous, it lies at the heart of being human and of being a religious being. To artificially separate the religious (spiritual) experience and orientation of a learner into certain facets that are allowed in school and others that are not, is to fail to understand the integral nature of religion and hence of spirituality and of being human. This, as we have seen, is not in the interest of promoting social justice and the search for the common or public good.

What would we gain by amending the South African Policy on Religion and Education (2003) so that it would provide social space for all the students' religious experiences in the formal school programme? Firstly, we would still have Religion Education as a formal examinable school subject, as stipulated by the Policy. Secondly, we would still have space for religious observances as currently provided for by the Policy. Thirdly and most importantly, we would have provided social space for religion instruction ('Religious Instruction', according to the Policy) during the formal school programme, under regulated circumstances and managed by teachers specially trained ${ }^{8}$ to present and manage diversity programmes. Instead of banning religious differences from the formal school programme we would have deliberate encounters with religious differences and diversity within the school programme, presented and managed by appropriately trained teachers.

In the social spaces specially designed for (confessional) religion instruction in schools, the students will be exposed to (inter alia) the numinous experiences of their classmates (Barge 2004:39), to the rationale behind the various rituals of the different religions, their worship practices, their dogmas, their ways of caring for others (essential for creating social capital, and for promoting social justice), their faith and belief structures and their spirituality. Jarvis (2008:71) is correct in saying that 'at this point different faiths can join together and this lies at the heart of inter-faith dialogue'.

The current approach bans religious diversity from schools as a measure to pre-empt possible religious conflict. This not only promotes ignorance about others and their religious tenets and peculiarities but also inspires suspicion about others and their faith. The alternative approach proposed above will promote deeper understanding and tolerance of others and what they believe (Gray 2006:307) and will contribute to the common good, that is, to the promotion of social justice and also to our store of social capital (Van der Walt 2009c:2-5). The promotion of Rawlsian justice as fairness (Rawls 2007:565) is closely connected to the development of ethical standards (see Scott \& Marshall 2009:381; Strauss 2009:515, 569; Nieuwenhuis 2010:15, and particularly Sankowski 2005:463).

\section{Conclusion}

This article commenced with the contention that religion has to be viewed from a post-structuralist interpretive-

8.This will obviously demand from teacher education institutions to reinstate the didactics of religion instruction. The approach will have to be different from that of the pre-1994 period, when such training used to be parochial in the sense that it concentrated only on the teaching of a single religion. Specialists for the proposed concentrated only on the teaching of a single religion. Specialists for the proposed diversity and not necessarily to inculcate the tenets of a particular religion. 
constructivist point of view. I offered several sets of evidence in support of this contention. I firstly argued that the view put forward by Abdool et al. (2007) and others about the structure of religion was incomplete in that it did not also embrace the notion of the numen (numinous), which is at the heart of religion. I then demonstrated that a structuralist view of religion was inadequate for a proper understanding of the dynamic nature of religion. A post-structuralist interpretive-constructivist view of religion enables us to construct a more sophisticated picture of religion. Evaluation of the current South African Policy on Religion and Education (2003) revealed that the Policy should be revisited to also provide for the teaching of confessional religion to older students for the purpose of inculcating knowledge, insight and understanding of the religious diversity in schools (and in the surrounding communities). Such understanding will lead to the more successful creation of social capital amongst South Africans and will contribute to greater social justice (fairness for all) and hence to the common good.

\section{References}

Abdool, A., Potgieter, F.J, Van der Walt, J.L. \& Wolhuter, C.C., 2007, 'Inter-religious dialogue in schools: a pedagogical and civic unavoidability', HTS Teologiese Studies/Theological Studies 63(2), 543-560.

Aronson, R., 2008, Living without God, Counterpoint, Berkeley, CA.

Augustine, Saint, 1909-1914, The Confessions of St Augustine, Book 8, pp. 354-430, The Harvard Classics, Harvard.

Babbie, E. \& Mouton, J., 2004, The practice of social research, Oxford University Press, Oxford.

Barge, L., 2004, 'Exploring the numinous in literature: Learning from Paul on Mars Hill', Journal of Education and Christian Belief 8(1), 35-52.

Calvin, J., 1584, Institution, transl. into the Afrikaans language by A. Duvenage \& L.J. du Plessis, 1951, Die Institusie van Calvyn, SACUM, Bloemfontein.

Chopra, D., 2009, The Third Jesus, Rider Books, London.

Colman, W., 2008, 'On being, knowing and having a self', Journal of Analytical Psychology 53, 351-366. doi:10.1111/j.1468-5922.2008.00731.x

Crosby, D.A., 2007, 'Further contributions to the dialogue', Journal for the Study of Religion, Nature \& Culture 1(4), 508-509.

Davies, P., 1992, The Mind of God: Science and the search for ultimate meaning, Penguin, London.

De Muynck, B. \& Van der Walt, J.L., 2006, The call to know the world, Buijten \& Schipperheijn, Amsterdam.

De Muynck, B., 2008, Een Goddelijk beroep, Groen, Herenveen.

De Villiers, J., 2009, 'Hare waai oor skolegodsdiens', Rapport, 20 September, p. 1.

Du Preez, M., 2009, Dwars: Mymeringe van 'n gebleikte Afrikaan, Zebra Press, Cape Town.

Feinberg, W. \& Soltis, J.F., 1985, School and society, Teachers College Press, New York.

Ferguson, R. \& Roux, C., 2004, 'Teaching and learning about religions in schools: Responses from a participation action research approach', Journal for the Study of Religion 17(2), 5-23.

Gibson, R., 1984, Structuralism and Education, Hodder and Stoughton, London.

Gray, D., 2006, 'Mandala of the self: embodiment, practice and identity construction in the Chakramsamvara tradition', The Journal of Religious History 30(3), 294-310.

Gray, J., 2003, Straw dogs, Granta Books, London. doi:10.1111/j.14679809.2006.00495.x

Greene, J.T., 2004, 'Covenant and Ecclesiology: Trusting human and God', Internationa Congregational Journal 4(1), 29-42.

Hagesaether, G. \& Sandsmark, S., 2006, 'Compulsory education in religion - the Norwegian case: an empirical evaluation of RE in Norwegian schools, with a focus on human rights', British Journal of Religious Education 28(3), 275-287. doi:10.1080/01416200600811402

Hewson, D. \& Carter, L., 2007, 'Book review. The idea of the numinous. Contemporary Jungian and Psychoanalytic perspectives', Journal of Analytical Psychology 52, Jungian and Psychoanalytic perspectives', Journal of
237-243. doi:10.1111/j.1468-5922.2007.00655_1.x

Jansen, J.D., 2009, Knowledge in the blood, Stanford University Press, Stanford, CA.

Jarvis, P., 2008, 'Religious experience: Learning and meaning', Transformation 25(2), $65-72$.

Kruger, J.S., Lubbe, G.J.A. \& Steyn, H.C., 1996, The human search for meaning, Via Afrika, Pretoria.
Kruger, P.P., 2009, 'Godsdiens in openbare skole... ja en nee', Die Kerkblad 112(3229), $10-12$.

Lagerweij, N. \& Lagerweij-Voogt, J., 2005, Anders kijken, Garant, Apeldoorn.

Leirvik, O., 2004, 'Religious education, communal identity and national politics in the Muslim world', British Journal of Religious Education 26(3), 223-236. doi:10.1080/0141620042000232283

Mathew, M., 2005, 'Reverie: between thought and prayer', Journal of Analytical Psychology 50, 383-393. doi:10.1111/j.0021-8774.2005.00539.x

McKay, V. \& Romm, N., 1992, People's Education in Theoretical Perspective, Maskew Miller-Longman, Pinelands.

McMillan, J.H. \& Schumacher, S., 2010, Research in education. Evidence-based inquiry, 7th edn., Pearson, Boston, MA.

Nieuwenhuis, J., 2010, 'Social justice in education revisited', paper presented at Örebro-Unisa International Conference, UNISA Muckleneuk Campus, Pretoria, 01-03 February.

Nolan, A., 2009, 'The spiritual life of the intellectual', in W. Gumede \& L. Dikeni (eds.), The poverty of ideas: South African democracy and the retreat of intellectuals, pp. 56-66, Jacana Media, Sunnyside.

Onwuegbuzie, A.J., Johnson, R.B. \& Collins, K.M.T., 2009, 'Call for mixed analysis: a philosophical framework for combining qualitative and quantitative approaches', International Journal of Multiple Research Approaches 3, 114-199.

Otto, R., 1923, The idea of the holy, viewed 14 December 2009, from http://books. google.co.za/books?id=0-9yrD6HOxUC\&dq=rudolf+otto\&printsec

Paley, J., 2008, 'Spirituality and Nursing: a reductionist approach', Nursing Philosophy 9, 3-18. doi:10.1111/j.1466-769X.2007.00330.x

Pickthall, M.M., 1994, Introduction to The Holy Q'uran, Millat Book Centre, Delhi.

Rawls, J., 2007, 'A theory of justice', in H. LaFolette (ed.), Ethics in practice, pp. 565-590, Blackwell, Malden, MA.

Republic of South Africa, 2003, 'National Policy on Religion and Education. National Education Policy Act, 1996 (Act no. 27 of 1996)', Government Gazette, 459(25459), Government Printers, Pretoria.

RSA (see Republic of South Africa).

Roux, C., 2003, 'Playing games with religion in education', South African Journal of Education 23(2), 130-134.

Roux, C., 2005, 'Religion in education: perceptions and practices', Scriptura 89(2), 293-306.

Roux, C., 2006, 'Innovative facilitation strategies for religion education', in M. de Souza, K. Engebretson, G. Durka, R. Jackson \& A. McGrady (eds.), Internationa Handbook of the Religious, Moral and Spiritual Dimensions in Education, part 2, pp. 1293-1306, Springer, Dordrecht. doi:10.1007/1-4020-5246-4_91

Roux, C. \& Du Preez, P., 2006, 'Religion in education: an emotive research domain', Scriptura 89(2), 273-282.

Sankowski, E.T., 2005, 'Justice', in T. Honderich (ed.), The Oxford Companion to Philosophy, pp. 463-464, University Press, Oxford.

Sayers, D.L., 2009, 'The Lost Tools of Learning', Redeemer Classical School, viewed 10 December 2009, from info@redeemerclassical.org/www.redeemerclassical.org.

Schlamm, L., 2007, 'C G Jung and the numinous experience: Between the known and the unknown', European Journal of Psychotherapy and Counselling 9(4), 403-414. doi:10.1080/13642530701725981

Scott, J. \& Marshall, G., 2009, Oxford Dictionary of Sociology, University Press, Oxford.

Sinclair, J.M., (ed.), 1999, Collins Concise Dictionary, HarperCollins, Glasgow.

Slater, T.S., 2004, 'Encountering God: personal reflections on geographer as pilgrim', Area 36(3), 245-253. doi:10.1111/j.0004-0894.2004.00221.x

Strauss, D.F.M., 2009, Philosophy: The discipline of the disciplines, Paideia Press, Grand Rapids, MI.

Swer, G.M., 2008, 'Nature, Physis and the Holy', Journal for the Study of Religion, Nature and Culture 2(2), 237-257.

Van der Walt, J.L., 2009a, 'So waai die hare oor skolegodsdiens!', Word and Action 49(410), 14-18. doi:10.1080/09637490903500507

Van der Walt, J.L., 2009b, 'Spirituality: the new religion of our time?', In die Skriflig 43(2), 251-269.

Van der Walt, J.L., 2009c, 'Metaphorical bridge-building for promoting understanding and peaceful coexistence', HTS Teologiese Studies/Theological Studies 65(1) 280-284.

Van der Walt, J.L., Potgieter, F.J. \& Wolhuter, C.C., 2010, 'The Road to Religious Tolerance in Education in South Africa (and Elsewhere): A Possible 'Martian Perspective', Religion, State and Society 38(1), 29-52.

Weisse, W., 2003, 'Difference without discrimination: religious education as a learning field for social understanding?', in R. Jackson (ed.), International perspectives on citizenship, education and religious diversity, pp. 191-208, RoutledgeFalmer, London.

Wikipedia, 2009a, 'Mandalas', viewed 10 December 2009, from http://images.google. co.za/images?sourceid=navclient\&rlz=1T4SKPB enZA282ZA283\&q=mandalas\&u $\mathrm{m}=1 \& \mathrm{ie}=U T F-8 \& \mathrm{ei}=8 \mathrm{DQhS}$-rQAeOZjAe7t|zbBw\&sa=X\&oi=image result group\&c

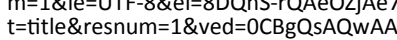

Wikipedia, 2009b, 'Numen', viewed 10 December 2009, from http://en.wikipedia.org/ wiki/Numen

Wilhelm, V., 2004, 'Body, Numinous, words', The Southern Review 40(3), 555-567.

Young, A.J., 2001, 'Mandalas. Circling the square in education', Encounter: Education for Meaning and Social Justice 14(3), 25-33. 